\title{
다차원적 빈곤과 불평등: 에티오피아 농촌지역의 극빈층을 중심으로
}

목 차

I. 서론

II. 빈곤의 다차원성

1. 1차원적 빈곤의 정의와 측정

2. 다차원적 빈곤(multidimensional poverty)

III. 빈곤과 불평등

1. 불평등의 정의

2. 빈곤과 불평등 간의 관계

IV. 빈곤과 불평등, 그리고 성장: 에티오피아 농촌지역 사례

1. 에티오피아 농촌지역의 빈곤

2. 에티오피아 농촌지역의 불평등

3. 에티오피아 농촌지역의 빈곤분해

4. 에티오피아 농촌지역의 다차원 빈곤함정

V. 결론

\section{I. 서론}

삶이 풍요로워지려면 소득과 직접 관련이 없지만 삶에 영향을 미칠 수 있는 다른 차원의 구성요소들이 만족되어야 할 것이다. 그렇지만 우리가 쉽게 사용하고 있는 빈곤척도는 단순히 소득만을 고려한 경우가 많다. 하루에 얼마를 소비할 수 있느냐 
를 기준으로 빈곤상태를 측정하는 행위는 삶의 다양한 측면을 고려하지 못했다. 즉 우리가 만일 빈곤퇴치를 1.25 달러 미만의 소비행위를 하는 사람의 숫자를 줄이는 것으로 이해하고 숫자를 줄이기 위해서만 노력한다면 결국 소득과 관계없지만 인간 의 삶에 영향을 미치는 다양한 사회적 병폐를 무시한 것이다. 이런 차원에서 빈곤은 다차원적으로 고려되어야 한다.

이러한 문제점을 인식한 Alkire and Foster(2011)는 다차원적 빈곤척도를 고안하 였다. 그들은 소득이외에 인간의 삶에 영향을 미치는 영양, 아동사망률, 위생, 전기, 식수접근성 등 다양한 측면을 척도에 포함하여, 경제가 성장해 소득이 증가해도 다 른 차원의 요인들이 여전히 빈곤한 상태에 놓일 수 있음을 보였다. 그러나 다차원적 빈곤에 대해 고려할 필요가 있는지 의문이 제기되기도 한다. 다차원빈곤지수를 활용 하여 얻을 수 있는 이점이 없다고 주장하기도 한다(Economist, 2014). 사실 $\mathrm{UNDP}(2014)$ 에서 보고된 다차원빈곤지수와 일 인당 GDP 간의 관계와 소득척도를 활 용한 빈곤인원수지수와 일인당 GDP 간의 관계를 비교하면 별다른 차이가 없어 보인 다(〈그림 1$\rangle)$.

<그림 1> 소득빈곤지수와 다차원빈곤지수의 비교
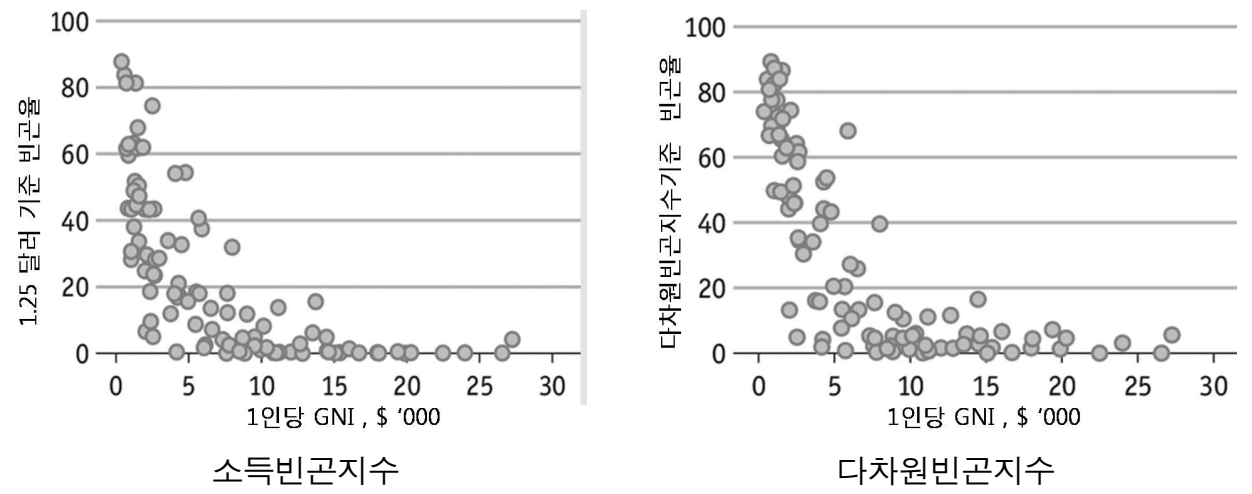

주: 2010년 구매력 지수로 변환된 GNI를 활용하였다.

출처: Economist(2014)를 재인용. 
그러나 이러한 국가별 자료를 활용한 단순비교는 평균이 가져다주는 착시일 수 있 다. 우리가 빈곤층(the poor) 가운데 극빈층(ultra-poor)에 관심을 둔다면 소득빈곤 지수와 다차원빈곤지수에서 다른 관계를 목격할 수 있을 것이다. 가구자료를 활용한 다면 극빈층은 다차원빈곤에 빠질 확률이 높고 더 나아가 영속적 빈곤함정에 빠질 가능성이 높을 것이다. 게다가 빈곤층 내부의 불평등은 결국 다차원적 빈곤과 연결 될 것이다. 따라서 본 연구는 이러한 가능성에대해 검토해 보고자 한다.

다차원빈곤의 역사는 불평등에 비해 상대적으로 짧다. Anand and Sen(1997) 이 후, Alkire and Foster(2011)가 척도를 고안하였다. Kwak and Smith(2010)는 다차 원적 빈곤이 빈곤함정의 새로운 원인일 수 있음을 주장했다. 예를 들어 가난한 농사 꾼은 자산이 없는 가난한 농장, 부실한 영양, 문맹 등 개별 제약들로 인해 소득이 더 디게 얻어질 수밖에 없다. 제약요인 중 일부가 완화된다고 해도 소득획득은 더디다. 왜냐하면 다른 제약요인이 완화된 요인이 성과가 나지 못하도록 방해하기 때문이다. 다시 말해 이러한 제약들은 서로가 서로를 강화시키는 특성이 있다. Dasgupta(1993) 도 자산함정(asset trap)과 부영양함정(malnutrition trap)이 동시에 가구의 생산성 을 낮출 수도 있음을 보였다.

본 연구는 다음과 같이 구성되어 있다. 제 2 장에서는 빈곤과 불평등의 정의를 논의 하고 다차원적 빈곤과 빈곤층 내부의 불평등에 대해 논의한다. 그리고 빈곤선 이상 에서 목격되는 불평등에 대해 간략히 서술한다. 제 3 장에서는 제 2 장의 서술을 바탕으 로 에티오피아농촌가구조사 자료를 활용하여 빈곤과 불평등, 성장간의 관계를 살펴 보고, 극빈층이 다차원적 빈곤에 의해 영향 받을 확률이 높음을 보인다. 마지막 제 4 장에서 결론을 제시한다.

\section{II. 빈곤의 다차원성}

최근 우리는 언론보도를 통해 빈곤과 불평등이라는 단어를 자주 접하고 있다. 두 개념이 한 사회가 처한 고통정도를 나타난다는 점에서 상호 밀접한 연관을 가지고 있지만 동일한 것은 아니다. 빈곤은 삶을 유지하기 위해 기본적으로 요구되는 필수 요소가 결핍된 상태를 의미하므로 생존권의 박탈과 연결된다. 반면에 불평등은 이러 
한 생존권의 직접적 박탈을 의미한다고 할 수 없다. 불평등은 대부분 분배문제와 연 결되어 결핍을 고착화시키는 기저로 작용할 뿐이지 결핍 그 자체는 아니기 때문이다. 다시 말해 불평등은 상대적인 개념으로 결핍을 겪고 있지 않은 대중들 사이에도 불 평등은 존재하고 결핍을 겪고 있는 빈곤층 사이에도 불평등은 존재할 수 있다는 의 미이다. 하지만 분배가 제대로 이루어지지 않는다면 사회구성원 중 일부는 고통을 느낄 수 있으므로 빈곤과 연결된다. 따라서 Sen(1981)과 Townsend(1970)는 불평등 을 재화나 권위가 박탈당하거나 전유되는 상태라고 정의한다. 본 장에서는 비슷하지 만 전혀 다른 개념인 빈곤과 불평등의 정의를 우선 논의하고 다차원적 빈곤과 불평 등에 대한 논의를 통해 빈곤과 불평등이 소득과 관계된 단순히 일차원적 문제가 아 님을 강조한다.

\section{1차원적 빈곤의 정의와 측정}

앞서 빈곤을 기본적 삶을 유지하기 위해서 요구되는 필수요소를 결핍한 상태라고 정의했다. 따라서 빈곤을 정의하기 위해서는 기본적 삶을 유지하기 위해 요구되는 필수요소가 무엇이며 그 양이 얼마인지 결정해야 한다. 다시 말해 빈곤을 정의내리 기 위해서는 절대적 빈곤선에 대한 규정이 필요하다. 세계은행은 하루 1.25 달러를 최 소한의 실질소득수준(국제적 빈곤선)으로 이용해왔다. ${ }^{1)}$ 2011년 세계은행의 추정에 의 하면 개발도상국에 거주하는 $17 \%$ 의 사람들이 하루 1.25 달러 미만으로 생활하고 있다 고 한다. 이 수치는 1981 년 52\%, 1990년 43\%에 비교하면 개선된 수치이다(세계은 행, 2015). ${ }^{2)}$ 빈민수도 1981년에 비해 2011년에 절반으로 줄어들어 약 10 억 명의 절 대빈곤층이 존재함을 확인할 수 있다.

1) 빈곤선은 실질단위로 일정하게 유지되므로 절대적 수준에서 시간의 흐름에 따라 개선 되는 양태를 비교할 수 있다는 장점이 있다. 그러나 빈곤을 단순히 1.25 달러 절대빈곤 선을 이용하여 측정하는 데는 한계점도 존재한다. 예를 들어 왜 1.25 달러가 빈곤선의 기준이 되느냐는 질문에 적정한 답을 제공하기 어렵다.

2) http://www.worldbank.org/en/topic/poverty/overview\#1(검색일: 2015년 1월 25일). 
〈표 1> 지역별 빈곤지수

(단위: \%, million)

\begin{tabular}{l|r|r|r|r|r|r|r|r}
\hline \multicolumn{1}{c|}{ 지 역 } & \multicolumn{2}{|c|}{1981} & \multicolumn{2}{c|}{1990} & \multicolumn{2}{c|}{2002} & \multicolumn{2}{|c}{2011} \\
\hline 동아시아 태평양 & 77.95 & $1,107.44$ & 57.01 & 939.11 & 27.34 & 518 & 7.93 & 160.76 \\
\hline 유럽/중앙아시아 & 2.92 & 12.55 & 1.54 & 7.15 & 2.13 & 10.01 & 0.49 & 2.35 \\
\hline 중남미 & 11.66 & 42.49 & 12.63 & 55.14 & 10.22 & 54.04 & 4.63 & 27.63 \\
\hline 중동/북아프리카 & 8.85 & 15.26 & 5.77 & 13.01 & 3.83 & 11.02 & 1.69 & 5.64 \\
\hline 남아시아 & 61.35 & 570.33 & 54.09 & 620.47 & 44.1 & 637.87 & 24.5 & 398.95 \\
\hline 사하라이남 아프리카 & 52.75 & 210.11 & 56.02 & 287.07 & 57.08 & 399.97 & 46.85 & 415.76 \\
\hline 전체 & 52.71 & $1,958.27$ & 43.35 & $1,921.74$ & 30.61 & $1,631.04$ & 16.99 & $1,011.37$ \\
\hline
\end{tabular}

주: 빈곤선은 하루 1.25 달러로 설정함.

출처: PovcalNet: the on-line tool for poverty measurement developed by the Development Research Group of the World Bank(http://iresearch.worldbank.org/PovcalNet/index.htm?1).

이처럼 절대빈곤은 소득이 절대빈곤선 이하인 사람들의 수 또는 인원수 (headcount)가 전체 인구에서 차지하는 비율로 측정할 수 있다. 그러나 이 측정법은 하루 0.25 달러로 생활하는 사람과 하루 1.15 달러로 생활하는 사람을 동일한 빈곤층 으로 여긴다는 한계가 있다. 왜냐하면 하루 0.25 달러로 생활하는 사람의 삶은 하루 1.15 달러로 생활하는 사람의 삶과 차이가 있을 것이다. 따라서 빈곤선 이하 빈곤층의 차이를 반영할 수 있는 새로운 측정방법이 요구된다. 이를 반영한 빈곤측정 지수가 빈곤갭지수(poverty gap index)이다. 빈곤갭지수는 빈곤선 이하의 모든 사람들이 빈 곤선 수준까지 올라서는데 필요한 소득의 총액이다. 빈곤갭지수를 국가 간 비교가 용이하도록 정규화한 지수를 정규 빈곤갭지수(NPG: Normalized Poverty Gap)라고 한다.

$$
\mathrm{NPG}=\frac{1}{N} \sum_{i=1}^{H} \frac{\left(Y_{p}-Y_{i}\right)}{Y_{p}}
$$

여기서 $\mathrm{H}$ 는 빈곤인원수, $\mathrm{N}$ 은 인구수, $Y_{p}$ 는 빈곤선, $Y_{i}$ 는 개별 빈곤 자 i의 소득 을 의미한다. 
$\mathrm{NPG}$ 를 활용해 국가 간 또는 지역 간 빈곤정도를 상호 비교할 수 있지만 빈곤선 이하 사람들의 소득불평등 정도를 나타내거나 비교할 수는 없다. 만일 경제에 충격 이 왔을 때 극빈층(ultra-poor)에 미치는 영향과 빈곤선 바로 이하에 위치한 빈곤층 에 미치는 영향은 다를 것이다. 이런 관점에서 Foster, Greer, and Thorbecke (1984)는 새로운 빈곤 측정도구를 제안했다. FGT 지수로 알려진 이 지수는 빈곤척도 가 갖추어야 할 기준(axioms)을 모두 만족하는 것으로 알려져 있고, ${ }^{3)} \alpha$ 가 0이면 빈 곤인원수 지수, $\alpha$ 가 1 이면 정규 빈곤갭지수, $\alpha$ 가 2 이면 빈곤심각도지수(PSI: Poverty Severity Index)가 된다. PSI는 빈곤의 깊이와 심각성에 대해 민감하게 반 응하므로 세계은행을 비롯한 주요 기관에서 소득빈곤측정의 기준으로 자주 사용되고 있다. 〈표 2〉에 따르면 사하라이남 아프리카의 빈곤문제가 전 세계에서 가장 심각한 것을 확인할 수 있다. 다시 말해 빈곤선에서 가장 멀리 위치하고 있는 극빈층이 사 하라이남 아프리카에 가장 많이 존재하고 있다는 의미이다.

$$
P_{\alpha}=\frac{1}{N} \sum_{i=1}^{H}\left(\frac{Y_{p}-Y_{i}}{Y_{p}}\right)^{\alpha}
$$

〈표 2〉 지역별 빈곤심각도 지수

\begin{tabular}{l|r|r|r|r}
\hline \multicolumn{1}{|c|}{ 지 역 } & \multicolumn{1}{c|}{1981} & \multicolumn{1}{c|}{1990} & \multicolumn{1}{c|}{2002} & \multicolumn{1}{c}{2011} \\
\hline 동아시아 태평양 & 19.53 & 8.74 & 3.08 & 0.47 \\
\hline 유럽/중앙아시아 & 0.35 & 0.2 & 0.19 & 0.09 \\
\hline 중남미 & 2.46 & 3.1 & 2.73 & 1.48 \\
\hline 중동/북아프리카 & 0.49 & 0.35 & 0.23 & 0.14 \\
\hline 남아시아 & 8.97 & 6.6 & 4.21 & 1.61 \\
\hline 사하라이남 아프리카 & 12.97 & 14.37 & 14.13 & 10.4 \\
\hline 전체 & 11.41 & 6.96 & 4.4 & 2.31 \\
\hline
\end{tabular}

주: 빈곤선은 하루 1.25 달러로 설정함.

출처: PovcalNet: the on-line tool for poverty measurement developed by the Development Research Group of the World Bank(http://iresearch.worldbank.org/PovcalNet/index.htm?1).

3) 빈곤척도는 익명성(anonymity), 인구독립성(population independence), 단조성 (monotonicity), 분포민감도(distributional sensitivity)를 만족해야 한다. 익명성이란 누가 가장 높은 소득을 얻고 있느냐가 빈곤지수 측정에 영향을 주지 않는다는 의미 이다. 인구독립성은 소득을 획득하는 사람들의 수에 의해 빈곤지수가 영향을 받지 않 는다는 의미이다. 예를 들어 인구대국과 인구소국을 동등하게 비교할 수 있어야 한다 는 의미이다. 
이상과 같이 절대빈곤은 빈곤선을 기준으로 측정될 수 있다. 그러나 빈곤을 단순 히 소득만 가지고 측정하는 것은 무리가 있다. 아래에서는 빈곤의 다차원성에대해 소개하고 최빈층에서 발현된 다차원적 빈곤은 소득증가만으로 해결될 수 없음을 강 조한다. 다차원적 빈곤을 겪고 있는 최빈층의 존재는 빈곤층 내부의 불평등을 심화 하는 기저로 작용하고 있다.

\section{2. 다차원적 빈곤(multidimensional poverty)}

제 I장

개

개발에 있어 개인의 역량(capability)을 강조한 $\operatorname{Sen}(1999)$ 은 소득만으로 빈곤을 측 정하는 데 한계가 있음을 지적했다. 국가 또는 지역적 상황에 따라 소득증가가 빈곤 감소에 기여하는 바가 다르고 소득보다는 자산의 증감이 빈곤 감소에 오히려 효과적 임이 여러 학자에 의해 강조되고 있다(Lybbert et al. 2004; Adato et al. 2006; Barrett et al. 2006; Naschold 2009; Kwak and Smith, 2013). 사실 자산의 종류 는 다양하다. 대부분 자산이라고 하면 물질을 먼저 떠올릴 수 있으나 비물질적 자산 이 개발에 있어 더욱 중요하다. 이러한 물질적·비물질적 자산의 증가는 $\operatorname{Sen}(1999)$ 의 다양한 차원의 역량배양과도 부합한다.

다차원적 빈곤은 처음 Anand and Sen(1997), Alkire and Foster(2011)에 의해 주목되었다. Kwak and $\operatorname{Smith}(2010)$ 은 극빈층(ultra-poor)은 빈곤을 구성하는 다차 원적 요인들이 얽혀 상호 영향을 미치고 있어(mutually reinforce) 빈곤에서 벗어나 지 못하고 결국 빈곤함정에 빠질 수밖에 없음을 강조했다. 왜냐하면 가계가 직면한 복합적인 결핍(multiple deprivation)들이 상호 부정적인 보완작용을 하기 때문이다. 예를 들어 보건, 교육, 생활수준(living standard)을 동시에 고려할 때, 3 부문 모두 극빈한 것으로 나타난 개인이나 가구에 보건 부문만을 개선시키는 지원이 이루어졌 어도 다른 두 부문이 개선되지 않는 한 결핍된 두 부문이 보건을 다시 악화시켜 빈 곤에서 벗어나지 못하게 한다는 의미이다. 이러한 빈곤함정의 존재는 빈곤층 내부의 불평등 정도를 악화시키고 정부와 국제사회의 빈곤감소 노력을 헛되게 만들 수 있다. 따라서 만성적 빈곤(chronic poverty)을 겪고 있는 가구가 다차원적 빈곤을 겪고 있 는지 검토해야 하고, 다차원적 빈곤의 정도가 극빈층에서 심각한 수준인지 확인할 필요가 있다. 또한 빈곤척도로써 단순히 소득수준에 의존해 빈곤을 측정한다면 이행 
적 빈곤(transitory poverty)을 겪고 있는 가구만을 측정에 포함하여 실제 빈곤정도 를 오도할 수 있다.

<표 3> 국가별 다차원빈곤지수

\begin{tabular}{l|r|r|r|r|r|r|r|r}
\hline \multirow{2}{*}{ 국 가 } & \multicolumn{5}{|c|}{ 다차원빈곤 } & \multicolumn{2}{|c|}{ 소득빈곤 } & \multirow{2}{*}{ 순위 } \\
\cline { 2 - 8 } & 인덱스 & 순위 & $\begin{array}{c}\text { 평균 } \\
\text { 결핍도 }\end{array}$ & 연도 & $\begin{array}{c}\text { 빈곤층 } \\
\text { 비중(\%) }\end{array}$ & $\begin{array}{c}1.25 \text { 달러 } \\
\mathrm{PPP} \%)\end{array}$ & 순위 & 차이 \\
\hline 아제르바이잔 & 0.009267 & 17 & 38.23932 & 2006 & 2.423427 & 0.43 & 11 & 6 \\
\hline 인도네시아 & 0.024363 & 25 & 41.26574 & 2012 & 5.903841 & 16.20 & 33 & -8 \\
\hline 콜롬비아 & 0.032124 & 32 & 42.2151 & 2010 & 7.609568 & 8.16 & 28 & 4 \\
\hline 필리핀 & 0.037696 & 35 & 51.93527 & 2008 & 7.258219 & 18.42 & 38 & -3 \\
\hline 페루 & 0.043196 & 37 & 41.35628 & 2012 & 10.44483 & 4.91 & 24 & 13 \\
\hline 볼리비아 & 0.096584 & 42 & 46.96621 & 2008 & 20.56456 & 15.61 & 32 & 10 \\
\hline 가나 & 0.144113 & 48 & 47.31907 & 2011 & 30.45564 & 28.59 & 46 & 2 \\
\hline 라오스 & 0.18592 & 50 & 50.49627 & 2011 & 36.81857 & 33.88 & 52 & -2 \\
\hline 네팔 & 0.196516 & 53 & 47.41615 & 2011 & 41.44489 & 24.82 & 44 & 9 \\
\hline 캄보디아 & 0.21118 & 55 & 45.1327 & 2010 & 46.79087 & 18.6 & 39 & 16 \\
\hline 방글라데시 & 0.236538 & 59 & 47.82179 & 2011 & 49.46246 & 43.25 & 55 & 4 \\
\hline 파키스탄 & 0.237243 & 60 & 52.03428 & 2012 & 45.59353 & 21.04 & 41 & 19 \\
\hline 나이지리아 & 0.238922 & 61 & 55.24128 & 2011 & 43.2506 & 67.98 & 70 & -9 \\
\hline 카메룬 & 0.260313 & 63 & 54.05914 & 2011 & 48.15338 & 9.56 & 29 & 34 \\
\hline 르완다 & 0.351591 & 73 & 49.67983 & 2010 & 70.77144 & 63.17 & 68 & 5 \\
\hline 우간다 & 0.358962 & 74 & 51.05596 & 2011 & 70.30749 & 38.01 & 53 & 21 \\
\hline 모잠비크 & 0.390015 & 77 & 55.58922 & 2011 & 70.1602 & 59.58 & 66 & 11 \\
\hline 콩고민주공 & 0.399347 & 78 & 53.66652 & 2010 & 74.41263 & 87.72 & 75 & 3 \\
\hline 에티오피아 & 0.537131 & 89 & 60.86631 & 2011 & 88.24772 & 30.65 & 48 & 41 \\
\hline & & & & & & & &
\end{tabular}

주: $\mathrm{DAC}$ 의 $\mathrm{ODA}$ 수원국 리스트에서 최빈국으로 분류된 국가를 볼드체로 표기하였다.

출처: UNDP. 2014 Human Development Reports(http://hdr.undp.org/en/content/table-6-multidimensional -poverty-index-mpi).

〈표 3〉은 다차원 빈곤지수를 한국의 중점협력국에 대해서 산출한 것이다. 국가별 로 편차가 존재하지만 소득빈곤지수와 다차원 빈곤지수가 반드시 일치하는 것은 아 니다. 특히 소득빈곤지수로 나타낸 순위보다 10순위 이상 뒤지는 다차원빈곤지수를 나타낸 국가는 페루, 볼리비아, 캄보디아, 파키스탄, 카메룬, 우간다, 모잠비크, 에티 오피아로 나타났다. 이 국가들은 DAC(Development Assistance Committee)의 ODA 
수원국 리스트에서 하위 중소득국과 최빈국으로 분류된다. ${ }^{4)}$ 따라서 최빈국들은 소득 측면에서 빈곤상황을 개선한 듯 보이지만 다차원적 빈곤이 존재하는 한 다시 빈곤상 태로 돌아갈 가능성을 항상 지니고 있다. 왜냐하면 Kwak and Smith(2011)이 지적 했듯이 결핍된 요인들이 상호 부정적인 보완작용을 하여 한 차원의 문제가 비록 개 선되었다 하더라도 다른 차원에 존재하는 문제가 다시 빈곤선 밑으로 끄집어 내릴 수 있기 때문이다. 이러한 측면에서 $\operatorname{UNDP}(2014$. p.72)는 다차원적 빈곤이 가계의 다른 속성과 상호작용할 경우 취약성(Vulnerability)이 더 증가할 수 있다고 하였다. 이 경우 빈곤층 내부의 불평등은 더욱 증가하게 되고 빈곤을 치유하기 위해 요구되 는 자원도 더욱 증가할 것이다.

\section{III. 빈곤과 불평등}

빈곤의 정의에 대해 앞 절에서 고려했다. 빈곤층 내부에도 불평등이 존재할 수 있 으며 극빈층(ultra-poor)과 빈곤선 바로 이하에 위치한 빈곤층간에 삶의 질과 빈곤 의 영속성(permanence)에 차이가 존재할 수 있음을 보였다. 본 절에서는 빈곤선보 다 높은 소득을 얻고 있는 개인 또는 가구들의 문제를 다루고자 한다.

\section{1. 불평등의 정의}

불평등의 정의는 연구자마다 사실 다르게 정의될 만큼 매우 복합적인 개념이다. 먼저 단순히 불평등을 경제적 지위관계에 기초하여 소득 또는 소비수준의 상대적 분 포로 정의내릴 수도 있다. 이처럼 계층별 분배로 불평등을 정의내리는 것은 분배구 조의 치우침을 드러낸다는 점에서 의의가 있으나 개인의 노동, 소비, 저축, 투자 등 과 같은 경제행위와 소득의 결정구조, 또는 상호관계를 고려하지 못한다는 점에서 한계가 있다. 다시 말해 계층별 분포를 가지고 정의된 불평등은 거시 경제이론을 통 해 설명하기가 쉽지 않다. 왜냐하면 개인이 어떤 방식으로 그리고 얼마나 생산에 참

4) 반면에 인도네시아, 필리핀, 라오스, 나이지리아 등 단지 4개국만이 다차원빈곤지수 순 위가 소득빈곤지수 순위보다 높게 나타났다. 다차원빈곤지수 순위를 보고하고 있는 국 가에 대해서는 55 개국이 소득빈곤지수로 나타낸 순위보다 떨어졌고, 순위가 올라간 국 가는 20 개국으로 대부분 상위중소득국에 속해 있었다. 예를 들어 세르비아, 벨 라루 스, 요르단, 태국, 몰디브 등이다. 
여했는가라는 문제가 불평등의 측정에 중요하게 관여되지 않았기 때문이다. 따라서 이 관점으로부터 불평등 완화방안을 제시하기가 쉽지 않다.

이러한 단점을 보완하기 위해 불평등을 소득의 기능별 또는 요소 지분(factor share)별 분배로서 정의내리기도 한다. 이 정의에 따르면 생산요소 각각의 상대가격 체계의 변화가 각 생산요소의 몫을 변화시키고, 사회의 분배상태도 변화시킨다. 즉 분배는 개인이나 가구가 생산에 기여하는 어떤 요소를 가지고 있느냐와 생산요소의 가격에 의해 결정된다. 개별 집단들은 저축과 소비성향에 차이(불평등)가 있으므로 자본축적을 위한 투자행위에서 차이가 나타나고, 경제성장에 미치는 영향 정도도 달 라진다. 따라서 불평등은 경제성장을 위한 필요악으로 해석될 수 있다. 그러나 이러 한 기능별 분배이론은 비 시장 동인(non-market force)의 역할과 영향력을 고려하 고 있지 못하다는 점에서 한계가 있다. 작금의 생산요소시장에는 요소가격을 왜곡하 는 고용주와 노동조합 간 단체 교섭, 또는 독점기업이 존재한다.

따라서 본 연구는 분석의 편의를 위해 불평등을 앞서 서술한 계층별 분포의 개념 으로 정의한다. 개인과 가구를 특정 소득 구간으로 나누고 그 구간에 위치한 개인과 가구들의 특성을 파악하고 사회·경제적 요인과의 관계를 분석한다면 정책대상의 설정 과 집행에 유용하기 때문이다.

\section{2. 빈곤과 불평등 간의 관계}

빈곤과 불평등은 모두 사회후생에 부정적 영향을 준다는 선입견을 가지고 있다. 물론 절대빈곤(absolute poverty)이 일정수준의 삶을 유지할 수 없는 결핍된 상태를 의미하므로 경제성장과 후생에 악영향을 준빈곤갭고 결론내리는 것은 당연하다. 그 러나 상대적 불평등도 감소가 경제성장을 통한 후생증가와 빈곤 감소에 긍정적 영향 을 미친다고 결론내리기에는 아직 증거는 부족하다. Dollar and Kraay(2002)는 불 평등 개선이 빈곤개선과 아무런 관계가 없으며, 단지 성장만이 빈곤율을 낮출 수 있 음을 보였다. 이들의 연구는 성장은 낙수효과(trickle-down effect)를 나타내므로 정 부의 불평등도 개선노력이 반드시 필요하지 않을 수 있다는 점을 강조했다. Lopez(2004)는 불평등도 개선이 성장에 영향을 준다는 유의한 증거를 찾지 못했다. 
$\operatorname{Kraay}(2006)$ 는 불평등 완화가 단기에서 빈곤 감소에 중요하지만, 장기에서는 성장이 빈곤 감소에 더 유의함을 보였다. Barro(2008)는 불평등도 심화가 빈곤국가에 부정 적 영향을 주지만 부유한 국가에는 긍정적 영향을 미침을 밝혔다. 다시 말해 빈곤국 가에서는 낮은 불평등도가 경제성장에 긍정적이라는 증거를 제시하였다.

그럼에도 불구하고 우리는 빈곤선 위에 위치한 개인과 가구의 상대적 불평등에 관 심을 가진다. 왜냐하면 불평등의 심화는 사회적 비효율을 가져오기 때문이다. 예를 들어 불평등도가 높은 사회에서는 보편적 교육보다는 고등교육을 강조하게 되고, 이 는 다시 소득불평등을 초래할 수 있다(Banerjee and Newmann, 1993). 또한 극심한 소득격차는 사회 불안정을 초래하는 동인으로 작용할 수 있다. 왜냐하면 높은 불평 등은 기득권을 보유한 자로 하여금 지대추구(rent seeking)행위를 할 유인을 제공한 다. 이 같은 행위는 자원의 비효율적 배분을 초래해 사회의 효율성을 떨어뜨리고, 사 회의 투명성도 낮출 수 있다. 반면에 불평등은 개인으로 하여금 추가적인 노동을 제 공하게 하는 유인으로 작용할 수 있다.

보편적으로 불평등을 불공정하다고 볼 수 있다. 〈그림 2〉에서 나타내듯이 경제성 장은 빈곤을 감소시킬 수 있다. 만일 소득 분포가 변화하지 않는다면 빈곤 감소는 오로지 성장에 의해서만 달성될 수 있다. 그러나 만일 성장이 없다면 빈곤 감소는 소득의 재분배에 의해서만 달성될 수 있다. 그러므로 결국 빈곤정도는 성장과 재분 배의 정도가 결정한다. 이는 빈곤변화를 성장과 불평등의 변화로 재구성할 수 있음 을 시사한다. 다음 절에서는 에티오피아의 농촌지역을 대상으로 빈곤과 불평등의 관 계를 살펴보도록 한다. 


\section{<그림 2> 빈곤-불평등-성장 간 관계}

빈 곤

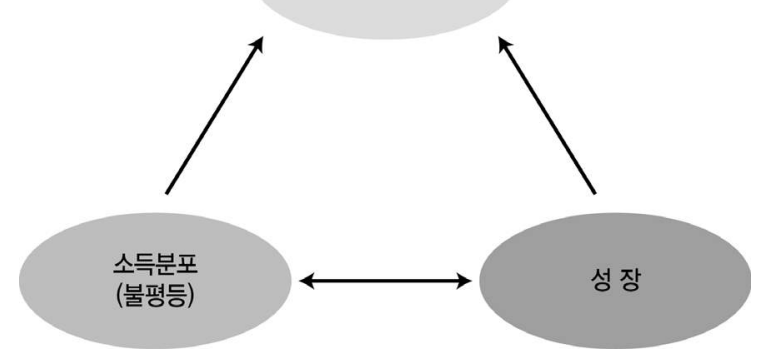

출처: The Poverty-Growth-Inequality Triangle(Bourguignon, 2004)

\section{IV. 빈곤과 불평등, 그리고 성장: 에티오피아 농촌지역 사례}

\section{1. 에티오피아 농촌지역의 빈곤}

\section{1) 에티오피아농촌가구조사}

에티오피아농촌가구조사(ERHS: Ethioipia Rural Household Survey)를 활용하여 빈곤과 불평등, 성장간의 관계를 살펴보고자 한다. 에티오피아의 농촌은 최빈국이지 만 친빈곤 성장정책(pro-poor growth)을 추진해 온 국가로 알려져 있다. 친빈곤 성 장은 빈곤층의 성장을 고려하므로 성장을 통해 불평등이 완화되는 모습을 보임과 동 시에 빈곤감소도 동시에 목격할 수 있다. 따라서 ERHS는 빈곤과 불평등, 성장간의 관계를 살펴보기에 적합한 자료이다. 또한 최빈국의 농촌지역에 대한 자료이므로 극 빈층의 모습을 나타내는 자료가 포함되어 있어 다차원적 빈곤의 모습도 살펴볼 수 있는 자료라는 점에서 의미가 있다.

ERHS는 국제식량정책연구소(IFPRI)에서 작성한 자료로 에티오피아 농촌 15 개 지 역, 1477 가구에 대한 정보를 포함하고 있다. 특히 자료의 설계가 에티오피아의 세 가지 농촌 환경 지역을 기준으로 구분되어 작성되어 있어 세 지역을 비교할 수 있다 는 장점도 보유하고 있다(〈그림 3 〉). 
<그림 3> 농법에 따른 에티오피아 농촌지역 구분

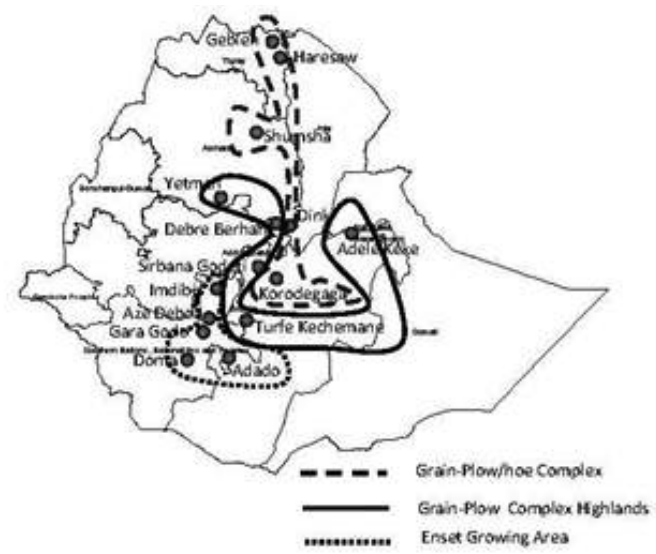

세 지역의 평균 실질 소비를 비교해 보면 엔셋 지역(Enset area)가 가장 빈곤한 지역임을 알 수 있다. 호 지역(Hoe area)은 중간, 하이랜드 지역(highland area)이 가장 부유한 지역으로 나타났다. 세 지역의 소득수준의 차이는 생산력의 차이에서 비롯된 것이다.5) 더불어 세지역간 인구이동이 제약되어 있다는 점은 각 지역의 빈곤 특성을 비교하기에 적합하다.

<표 4> 농업 지역별 1인당 평균 실질소비

\begin{tabular}{c|c|c|c|c|c}
\hline & 전체 표본 & Highlands & Hoe & Enset & $\mathrm{N}$ \\
\hline 1994 & 72.15 & 95.54 & 64.70 & 51.87 & 1,477 \\
1995 & 64.45 & 81.39 & 61.70 & 47.12 & 1,421 \\
1997 & 92.58 & 120.67 & 81.99 & 69.91 & 1,402 \\
1999 & 90.55 & 117.28 & 90.36 & 57.00 & 1,360 \\
2004 & 91.54 & 119.33 & 83.92 & 66.35 & 1,294 \\
\hline Total & 81.91 & 106.47 & 76.15 & 58.28 & 6,954 \\
\hline
\end{tabular}

주: 모든 화폐가치는 1994년으로 조정되었다.

출처: ERHS 1994, 1995, 1997, 1999, 2004.

5) 지역의 차이에 대한 정보는 Kwak and Smith(2011)을 참조하라. 


\section{2) 에티오피아 농촌 지역의 빈곤}

〈표 5〉는 시간에 따라 농촌지역의 빈곤지수(FGT 지수) 변화를 나타낸다. 빈곤이 가장 빈번한 지역은 엔셋 지역(Enset area)로 나타났다. 시간에 따라 일인당 소비가 증가하면서 3 지역 모두에서 빈곤감소를 목격할 수 있었다. 호 지역(hoe area)의 빈 곤인원수지수 $\left(P_{0}\right)$ 가 1994 년부터 2004 년까지 $21 \%$ p 감소하여 가장 큰 폭의 감소를 나 타냈다. 빈곤선에 도달하기 위해 부족한 평균소득을 나타내는 정규빈곤갭지수 $\left(P_{1}\right)$ 도 호 지역(hoe area)에서 가장 크게 감소했다. 빈곤층 내부의 불평등이 완화되었는지 를 확인하기 위해 계산된 빈곤심각도지수 $\left(P_{2}\right)$ 를 살펴보면 3 지역 가운데 가장 빈곤 한 지역인 엔셋 지역(Enset area)에서 가장 심각한 것으로 나타났다.

<표 5> 연도별 농법지역별 빈곤

\begin{tabular}{c|c|c|c|c|c|c|c|c|c}
\hline & \multicolumn{4}{|c|}{$P_{0}$} & \multicolumn{3}{c|}{$P_{1}$} & \multicolumn{3}{c}{$P_{2}$} \\
\hline Year & Highland & Hoe & Enset & Highland & Hoe & Enset & Highland & Hoe & Enset \\
\hline 1994 & 0.29 & 0.57 & 0.61 & 0.10 & 0.26 & 0.30 & 0.05 & 0.14 & 0.18 \\
1995 & 0.37 & 0.56 & 0.74 & 0.12 & 0.24 & 0.38 & 0.06 & 0.13 & 0.24 \\
1997 & 0.16 & 0.37 & 0.48 & 0.05 & 0.12 & 0.19 & 0.02 & 0.05 & 0.10 \\
1999 & 0.23 & 0.30 & 0.59 & 0.07 & 0.10 & 0.24 & 0.03 & 0.05 & 0.13 \\
2004 & 0.23 & 0.36 & 0.51 & 0.07 & 0.12 & 0.22 & 0.03 & 0.06 & 0.12 \\
\hline total & 0.25 & 0.44 & 0.59 & 0.08 & 0.17 & 0.27 & 0.04 & 0.09 & 0.15 \\
\hline
\end{tabular}

출처: ERHS 1994, 1995, 1997, 1999, 2004.

농법지역에 따라 FGT 빈곤지수를 분해할 수 있다. 빈곤지수를 지역에 따라 나누 면 다음과 같이 나타내진다.

$$
\widehat{P}(z ; \alpha)=\sum_{g=1}^{G} \hat{\phi}(g) \hat{P}(z ; \alpha, g)
$$

여기서 $\mathrm{G}$ 는 서브그룹의 숫자를 의미하고 $\hat{\phi}(\mathrm{g})$ 는 서브그룹의 인구비율, $\mathrm{z}$ 는 빈곤 선, $\alpha$ 는 빈곤지수의 종류를 의미한다. 서브그룹 $\mathrm{g}$ 가 총빈곤에서 차지하는 상대적 비 
중은 $\frac{\hat{\phi}(g) \hat{P}(z ; \alpha, g)}{\hat{P}(z ; \alpha)}$ 로 나타내진다. 〈표 6〉은 총빈곤에 대한 엔셋 지역의 절대적 기 여도가 시간의 흐름과 함께 감소함을 나타내고 있다. 그러나 상대적 빈곤도는 시간 이 흐를수록 증가함을 확인할 수 있다. 다시 말해 절대빈곤층의 숫자가 감소하고 있 음을 의미한다. 호지역은 상대적 기여측면에서 감소하는 경향이 있다. 에티오피아 농 촌의 빈곤에 가장 크게 영향을 준 지역은 엔셋(Enset)으로 총 빈곤대비 상대적 기여 도가 시간의 흐름에 따라 가장 크게 증가하고 있다. 이 결과는 다른 지역에 비해 상 대적으로 적은 인원만이 빈곤에서 벗어나고 있음을 의미한다.

\section{제 I장}

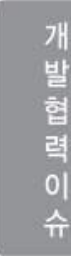

제II장

제피장

제IV장

\begin{tabular}{l|c|c|c|c|c|c|c|c}
\hline & \multicolumn{4}{|c|}{ 절대적 기여도 } & \multicolumn{4}{c}{ 상대적 기여도 } \\
\hline & 인구비율 & 1994 & 1999 & 2004 & 인구비율 & 1994 & 1999 & 2004 \\
\hline Highlands & 0.093 & 0.106 & 0.084 & 0.083 & 0.225 & 0.220 & 0.235 & 0.233 \\
Hoe & 0.145 & 0.191 & 0.101 & 0.117 & 0.349 & 0.396 & 0.282 & 0.330 \\
Enset & 0.177 & 0.186 & 0.173 & 0.155 & 0.426 & 0.384 & 0.484 & 0.437 \\
\hline
\end{tabular}

주: 절대적 기여도는 빈곤인원수 지수에 지역의 인구비율을 곱하여 계산된다. 상대적 기여도 는 절대적 기여도를 빈곤인원수 지수로 나눈 것이다.

출처: ERHS 1994, 1995, 1997, 1999, 2004를 패널자료로 연결하여 사용하였다.

그러므로 농법지역별로 빈곤지수의 성격이 다를 뿐 아니라 빈곤층 내부의 분배상 태도 다름을 확인할 수 있다. 빈곤의 다양성은 〈표 7〉에 나타난 빈곤의 성장탄력성 (growth elasticity of poverty)에서 더욱 두드러져 보이는데, 탄력성 값은 성장이 빈곤에 미치는 영향 정도를 나타낸다. 탄력성은 빈곤선 아래의 분포를 반영하는 빈 곤갭 또는 빈곤심각도 지수에서 크게 나타나는 경향이 있다. 또한 에티오피아의 농 촌 지역 가운데 가장 빈곤한 엔셋 지역이 가장 높은 탄력성을 나타내고 있으며 가장 잘사는 하이랜드 지역이 가장 낮은 값을 나타내고 있다. 성장이 빈곤선 아래에 위치 한 최빈층의 불평등을 완화하는 정도가 가장 못사는 지역에서 크게 나타남을 의미한 다. 반면에 성장이 빈민수를 줄이는 데 있어서는 잘사는 지역과 못사는 지역에서 편 차가 없는 것으로 보인다. 왜냐하면 빈곤인원수 지수에 대한 성장 탄력성이 유사하 게 추정되었기 때문이다. 그렇지만 성장의 어떤 측면이 빈곤정도를 감소시키는지 탄 력성 추정을 통해서 알 수 없다는 한계점이 있다. 
〈표 7> 빈곤의 성장 탄력성

\begin{tabular}{l|c|c|c|c|c|c}
\hline & \multicolumn{2}{|c|}{$P_{0}$} & \multicolumn{2}{c|}{$P_{1}$} & \multicolumn{2}{c}{$P_{2}$} \\
\hline & Elasticity & SE & Elasticity & SE & Elasticity & SE \\
\hline Highlands & -1.053 & 0.070 & -1.041 & 0.100 & -0.982 & 0.117 \\
Hoe & -1.257 & 0.083 & -1.603 & 0.103 & -1.806 & 0.148 \\
Enset & -1.126 & 0.101 & -1.943 & 0.126 & -2.524 & 0.160 \\
Population & -1.150 & 0.061 & -1.499 & 0.072 & -1.720 & 0.081 \\
\hline
\end{tabular}

출처: ERHS 1994, 1995, 1997, 1999, 2004를 패널자료로 연결하여 사용하였다.

\section{2. 에티오피아 농촌지역의 불평등}

불평등은 빈곤선을 기준으로 크게 두 부분으로 나눌 수 있다. 먼저 빈곤선 이하에 존재하는 불평등은 빈곤의 심각성을 이해하는데 중요함을 알 수 있었다. 그렇지만 빈곤선 이상에 존재하는 불평등도 사회의 후생증대를 위해 분석할 필요가 있음을 앞 서 강조했다. 왜냐하면 높은 불평등은 사회가 보유한 자원을 비효율적으로 배분하게 만들어 평균 소득과 성장률을 낮출 수 있기 때문이다. 에티오피아의 불평등 정도를 지니 지수와 GE(Generalized Entropy)지수를 활용하여 추정한다.6) 이를 통해 성장 과 불평등, 불평등과 빈곤과의 관계를 연구한다.

〈표 8〉은 성장이 불평등에 미치는 효과를 나타낸다. 불평등 추세는 지역마다 달랐 는데, 호 지역은 시간의 흐름과 함께 감소하였지만, 하이랜드와 엔셋 지역은 증가하 거나 그 상태를 그대로 유지했다. 그러므로 빈곤의 변화만큼이나 불평등의 변화도 지역별로 상이하다고 결론 내릴 수 있다. 따라서 지역별로 성장, 빈곤, 불평등의 관 계가 다르게 나타난 다고 결론내릴 수 있다. 경제가 성장할 때, 세 지역에서 모든 빈 곤척도가 감소했지만 불평등은 다른 양태를 보였다. 상대적으로 소득이 높은 하이랜

6) GE지수는 0 부터 무한대까지 이 숫자를 가지는데, 더 높은 값이 더 높은 불평등을 의 미한다. GE 지수는 $\theta$ 의 값이 낮을 때(높을 때) 분포의 하단(상당)부근 즉 최빈층(부유 층)에서 더 민감하게 변화한다. $\theta$ 가 1 이라면 분포의 모든 지점에서 동일한 민감도를 가진다. GE 지수는 다음 공식으로 계산된다.

$$
I(\theta)=\frac{1}{\theta(\theta-1) \sum_{i=1}^{n} w_{i}} \sum_{i} w_{i}\left[\left(\frac{y_{i}}{\bar{y}}\right)^{\theta}-1\right]
$$


드 지역은 1994년부터 2004년까지 불평등이 증가했지만, 소득이 중간정도인 호 지역 에서는 불평등이 감소했다. 소득이 가장 낮은 엔셋 지역은 불평등이 감소했다고 할 수 없었다.

〈표 8> 지니와 GE 지수

\begin{tabular}{c|c|c|c|c|c|c}
\hline & \multicolumn{3}{|c|}{ Gini } & \multicolumn{3}{c}{ GE( $=0)$} \\
\cline { 2 - 7 } & 1994 & 1999 & 2004 & 1994 & 1999 & 2004 \\
\hline Highlands & 0.401 & 0.389 & 0.428 & 0.280 & 0.260 & 0.320 \\
Hoe & 0.476 & 0.391 & 0.393 & 0.390 & 0.267 & 0.265 \\
Enset & 0.423 & 0.398 & 0.429 & 0.321 & 0.266 & 0.321 \\
\hline 전지역 & 0.451 & 0.419 & 0.435 & 0.361 & 0.304 & 0.332 \\
\hline
\end{tabular}

출처: ERHS 1994, 1995, 1997, 1999, 2004를 패널자료로 연결하여 사용하였다.

\section{3. 에티오피아 농촌지역의 빈곤분해}

빈곤정도의 변화를 순수한 성장과 재분배효과로 나우어 이해하는 것은 빈곤과 성 장간의 관계를 이해하는데 도움이 된다. Datt and Ravallion(1992)은 기준시점 $\mathrm{r}$ 기 와 $\mathrm{t}$ 기와 $\mathrm{t}+\mathrm{n}$ 의 두 기간 동안의 빈곤변화를 다음과 같이 나타냈다.

$$
P_{t+n}-P_{t}=G(t, t+n ; r)+D(t, t+n ; r)+R(t, t+n ; r)
$$

두 긴간동안의 빈곤의 총 변화 $P_{t+n}-P_{t}$ 는 성장 $(\mathrm{G})$, 재분배(D), 잔차 $(\mathrm{R})$ 로 구성 된다. 성장부문과 재분배부문은 다시 각각 $G(t, t+n ; r) \equiv P\left(\mu_{t+n} ; L_{r}\right)-P\left(\mu_{t} ; L_{r}\right)$ 와 $D(t, t+n ; r) \equiv P\left(\mu_{r} ; L_{t+n}\right)-P\left(\mu_{r} ; L_{t}\right)$ 로 나타낼 수 있으며, 여기서 $\mu$ 는 일인당 평 균소득을 $\mathrm{L}$ 은 불평등도를 의미한다. 자료의 최초 분포를 기준(reference period)으로 삼았을 때, 성장과 재분배의 분해에 대한 평균을 구하면 잔항항은 사라진다.

〈표 9〉는 1994년부터 2004년까지 에티오피아 농촌지역의 빈곤분해 결과를 나타낸 다. 세 지역 모두에서 성장부문이 재분배부문을 압도했다. 예를 들어 빈곤인원수 지 수가 1994 년부터 2004 년까지 $12.7 \%$ p 감소했는데, 이를 분해할 경우 $11.6 \%$ 만큼 성 장이 기여했고, $1.1 \%$ p만큼 재분배가 기여한 것으로 나타났다. 이 결과를 다시 해석 
한다면 성장이 없었다면 빈곤은 단지 $1.1 \%$ p만큼만 감소한 것이 된다. 흥미로운 것은 빈곤선 미만에 위치한 사람들의 불공평은 상대적으로 경제성장만으로는 해소하기 어 려워 보인다. 왜냐하면 빈곤 감소에 성장부문이 차지하는 비율이 $P_{0}$ 에서 $P_{1}, P_{2}$ 로 갈수록 점점 작아지기 때문이다. 또한 지역에 따라 성장과 재분배가 빈곤에 미치는 영향이 다르게 나타났다는 점은 빈곤감소를 위한 정책이 지역별로 다르게 집행될 필 요가 있음을 의미한다.

<표 9> 빈곤분해: 성장과 재분배

\begin{tabular}{l|c|c|c|c|c|c|c|c|c|c|c|c}
\hline & \multicolumn{3}{|c|}{ All Regions } & \multicolumn{3}{c|}{ Highlands } & \multicolumn{3}{c|}{ Hoe } & \multicolumn{3}{c}{ Enset } \\
\cline { 2 - 13 } & $P_{0}$ & $P_{1}$ & $P_{2}$ & $P_{0}$ & $P_{2}$ & $P_{2}$ & $P_{0}$ & $P_{2}$ & $P_{2}$ & $P_{0}$ & $P_{2}$ & $P_{2}$ \\
\hline 빈곤변화 & -12.7 & -8.0 & -5.2 & -6.4 & -3.0 & -1.3 & -21.4 & -13.7 & -8.9 & -11.0 & -7.9 & -6.0 \\
성장 요소 & -11.6 & -6.1 & -3.7 & -8.9 & -4.0 & -2.0 & -14.1 & -7.5 & -4.6 & -127 & -7.9 & -5.3 \\
재분배 요소 & -1.1 & -1.9 & -1.5 & 2.5 & 1.0 & 0.7 & -7.3 & -6.2 & -4.3 & 1.7 & -0.1 & -0.7 \\
\hline
\end{tabular}

출처: ERHS 1994, 1995, 1997, 1999, 2004를 패널자료로 연결하였다.

\section{4. 에티오피아 농촌지역의 다차원 빈곤함정}

에티오피아의 농촌지역은 가장 빈곤한 지역으로 알려져 있다. 연구의 편의를 위해 농가가 보유한 자산을 adato et al.(2006)의 방법론을 사용하여 자사지수를 산출하 였다. 다차원 빈곤을 규명하기 위해 아이들의 BMI 지수를 활용하여 가구마다 부영양 를 식별하였고,7) 가구주가 글을 읽을 수 있는지 여부를 자료를 통해 식별하였다. 5 개 설문조사에서 연속으로 가구주가 글을 읽지 못하는 것으로 나타나면 그 가구는 문맹함정에 빠진 것으로 분류하였다. 부영양함정도 동일한 기준으로 분류하였다. 함 정의 유무에 따라 자산정도를 비교하면 다음 〈표 10〉과 같다.

7) 가구원 누구든 나이별 BMI가 -2보다 작으면 부영양 상태 가구로 규정하고 5기간 동안 연이어 부영양상태가 지속된다면 부영양함정에 빠진 것으로 정의하였다. 
〈표 10〉 빈곤함정 상태와 평균 자산지수

\begin{tabular}{c|c|c|c|c|c|c|c}
\hline \multirow{2}{*}{} & \multicolumn{2}{|c|}{ 부영양함정 } & \multicolumn{2}{c|}{ 문맹함정 } & \multirow{2}{*}{ 무 } & \multirow{2}{*}{ 단일함정 } & \multirow{2}{*}{ 이중함정 } \\
\cline { 2 - 5 } & No & Yes & No & Yes & & & \\
\hline \multirow{2}{*}{ 전체 } & 2.322 & 1.672 & 2.252 & 2.040 & 2.363 & 2.104 & 1.588 \\
& $(82.1 \%)$ & $(17.9 \%)$ & $(49.5 \%)$ & $(50.5 \%)$ & $(45.6 \%)$ & $(54.6 \%)$ & $(12.1 \%)$ \\
\hline \multirow{2}{*}{ Highlands } & 3.009 & 2.644 & 2.903 & 2.951 & 2.964 & 2.914 & 2.717 \\
& $(89.9 \%)$ & $10.1 \%)$ & $(54.4 \%)$ & $(45.6 \%)$ & $(50.6 \%)$ & $(49.4 \%)$ & $(6.4 \%)$ \\
\hline \multirow{2}{*}{ Hoe } & 2.072 & 1.724 & 2.120 & 1.977 & 2.229 & 1.979 & 1.747 \\
& $(84.0 \%)$ & $(16.0 \%)$ & $(43.9 \%)$ & $(56.1 \%)$ & $(39.4 \%)$ & $(60.6 \%)$ & $(11.4 \%)$ \\
\hline \multirow{2}{*}{ Enset } & 1.544 & 1.229 & 1.631 & 1.268 & 1.701 & 1.379 & 1.103 \\
& $(70.8 \%)$ & $(29.2 \%)$ & $(49.5 \%)$ & $(50.5 \%)$ & $(44.0 \%)$ & $(56.0 \%)$ & $(18.6 \%)$ \\
\hline 관측치 & 4,817 & 1,048 & 2,255 & 2,303 & 1,826 & 2,179 & 553 \\
\hline
\end{tabular}

주: ( )는 주어진 함정을 가진 가구의 비율을 의미한다.

출처: ERHS 1994, 1995, 1997, 1999, 2004를 패널자료로 연결하여 사용하였다.

전체적으로 함정에 빠진 가구의 자산상태가 낮은 것으로 나타났다. 또한 단일함정 에 빠진 가구보다 이중함정(다차원함정)을 겪고 있는 가구의 자산이 가장 낮은 것을 확인할 수 있다. 자산도 가장 못사는 지역인 엔셋이 가장 낮은 수준을 기록하고 있 었다. 따라서 가장 못사는 지역으로 갈수록 다차원적 빈곤이 나타날 확률이 높아짐 을 확인할 수 있다. 〈표 8〉과 함께 다차원 빈곤상태를 고려해보면 가장 못사는 지역 에서 불평등도가 가장 높을 뿐만 아니라 다차원 빈곤을 심각하게 겪고 있는 것을 확 인할 수 있다. 자산의 축전이 가장 낮다는 의미는 이 지역에서 자산의 결핍도 경험 하고 있다는 의미로 해석되므로 엔셋 지역은 3차원 빈곤을 겪고 있는 것이다. 또한 〈표 5〉가 나타냈듯이 엔셋 지역에서 빈곤선 이하 불평등이 가장 심하게 나타나고 있 다는 점은 다차원빈곤과 불평등간의 연결고리를 시사한다. 한편 가장 못사는 지역에 서 가장 큰 성장의 빈곤탄력성 값이 보고되었으므로 다차원빈곤을 없애기 위한 방법 을 성장에서 찾아야 할 것이다. 그러나 빈곤선 이하에서 발생하는 불평등의 심각성 을 고려할 때 성장은 일차원적인 소득증가가 아니라 다양한 차원의 자산의 증가로 달성되어야 함을 시사한다. 


\section{V. 결론}

경제발전을 단순히 소득증가라는 측면에서 이해하는 것이 바람직한 것인가에 대한 논의가 필요하다. 경제발전을 단편적인 소득으로만 이해를 하는 것은 발전이 다양한 측면에서 동시에 일어난다는 현상을 제대로 설명하지 못할 수 있다. 왜냐하면 한나 라의 경제발전은 소득 증가와 더불어, 교육과 보건수준의 증가, 공공서비스에 대한 접근성 증가, 정치적 참여기회 확대 등 다양한 측면으로 이해되어야하기 때문이다.

한편 아프리카의 일부 개발도상국은 일인당국민소득의 증가를 통해 정권유지의 당 위성을 홍보하기도 한다. 그러나 일인당국민소득의 증가가 과연 경제발전을 나타낼 수 있을까? 1 인당국민소득이 다양한 방식으로 증가할 수 있음을 고려할 경우 빈곤 감소를 위해 최선의 방식이 무엇인가에 대한 고민이 필요하다. 이 고민은 불평등과 직접 연관된다. 모든 경제주체의 소득이 동일하게 증가할 경우, 우리는 불평등에 대 해 논의할 필요가 없다. 반면에 일부 자산가가 경제성장을 주도하고 경제성장의 과 실이 생산에 참여한 사람에게 제대로 전달되지 못한다면 우리는 불평등을 목격하게 된다. 경제성장의 과실이 소득이라는 형태로 경제주체에 잘 분배되었다면 불평등문 제는 나타나지 않았을 것이다. 물론 이 과정에서 생산에 참여할 수 있는 기회가 공 정하게 주어졌느냐의 문제가 먼저 거론될 필요가 있다.

본 연구는 이런 관점에서 다차원적 빈곤에 대한 고려하였다. 에티오피아 농촌의 가구처럼 빈곤층은 다양한 차원의 빈곤을 경험하고 있다. 특히 극빈층이 가장 많이 분포하는 지역일수록 다차원적 빈곤을 경험할 가능성이 높았고 빈곤층 내부의 불평 등도 높게 나타났다. 이 경우 경제성장이 유일한 해결 방안이었으나 단순이 소득의 이전으로 빈곤문제가 해결되지 않음을 강조했다. 왜냐하면 다차원적 빈곤은 빈곤함 정의 원인이기 때문이다. 빈곤함정이 존재할 때 단편적인 소득 이전 프로그램은 실 패할 확률이 높다. 따라서 빈곤층 지원프로그램은 다양한 차원을 커버할 수 있는 종 합적인 체계를 갖추어야 한다. 사실 빈곤층 지원프로그램에 참여하고 있는 사람들이 자신들의 나쁜 영양상태, 부적절한 위생환경, 식수부족, 사회적 배제, 낮은 교육수 준, 열악한 주거환경, 폭력, 정치적 배제 등 다양한 측면에 걸쳐 자신들이 열악한 삶 을 살고 있다고 설문조사에서 보고한다 $(\mathrm{ERHS})$. 따라서 정책입안자나 실무자들은 빈 
곤에 대한 더 유용한 관련 정보를 수집할 필요가 있다. 그래야만 제대로 된 정책대 안으로 빈곤을 줄일 수 있다. 예를 들어 교육여건이 부족한 지역에 거주하는 빈곤층 에 대한 정책은 주거환경이 열악한 지역에 거주하는 빈곤층과 구별되는 빈곤감소 정 책이 요구될 것이다. 에티오피아 농촌 지역도 3 지역의 특성 각각 달라 빈곤감소 프 로그램도 달라질 필요가 있었다.

본 연구는 다차원적 빈곤과 빈곤선 이하 불평등의 관계에 대해 제시하였다. 그러 나 에티오피아 농촌지역 자료를 활용해 엄밀한 계량경제학적 분석을 수행하지 못했 다는 한계점이 있다. 두 변수 간 관계에 관한 엄밀한 분석은 빈곤의 실상을 이해하 는데 도움이 될 뿐만 아니라 빈곤감소 프로그램의 효율적 구성에 기여할 것이다.

\section{제 I장}

개 


\section{참고문헌}

Adato, Michelle, Michael Carter, and Julian May. 2006 "Exploring Poverty Traps and Social Exclusion in South Africa using Qualitative and Quantitative Data." The Journal of Development Studies, Vol. 42, No. 2, pp. 226-247.

Alkire, S. and Foster, J. 2011. Counting and Multidimensional Poverty Measurement. Journal of Public Economics, 95. pp. $476-487$.

Anand, A. and Sen, A. 1997. Concepts of Human Development and Poverty: A Multidimensional Perspective. Human Development Papers, pp. 1-19.

Banerjee, V. Abhijit and Andrew F. Newmann. 1993. "Occupational choice and the process of development," Journal of Political Economy 101. pp. 274-298

Barrett, Christopher, Paswel Phiri Marenya, John Mcpeak, Bart Minten, Festus Murithi, Willis Oluoch-Kosura, Frank Place, Jean Claude Randrianarisoa, Jhon Rasambainarivo, and Justine Wangila. 2006. "Welfare Dynamics in Rural Kenya and Madagascar." The Journal of Development Studies, Vol. 42, No. 2, pp. 248-277.

Barro, Robert J. 2008. "Inequality and Growth Revisited." ADB Working Paper Series on Regional Economic Integration, Vol. No. 11.

Bourguignon, Francois. 2004. The Poverty-Growth-Inequality Triangle. Indian Council for Research on International Economic Relations.

Dollar, David and Aart Kraay. 2002. "Growth is Good for the Poor." Journal of Economic Growth, Vol. 7, No. 3, pp. 195-225. 
Economist. 2014. Poverty Measures: Width, not depth, Jul 28th. 2014.

London(http://www. economist.com/blogs/freeexchange/201 4/07/poverty-measures)

제 I장

Kraay, Aart. 2006. "When is Growth Pro-Poor? Evidence from a Panel of Countries." Journal of Development Economics, Vol. 80, No. 1, pp. 198-227.

Kwak, Sungil and Stephen C. Smith. 2010. "What Kind of Poverty Trap? An Investigation of single and multidimensional poverty traps with Ethiopian household panel data," paper presented at the Northeast Universities Development Conference, MIT, Nov. 6-7.

------------. 2011. Multidimensional Poverty and Interlocking Poverty Traps: Framework and Application to Ethiopian Household Panel Data, Working Papers 2011-04, The George Washington University, Institute for International Economic Policy

------------. 2013. "Regional Agricultural Endowments and Shifts of Poverty Trap Equilibria: Evidence from Ethiopian Panel Data," The Journal of Development Studies, Vol. 49. No.7. pp. 955-975

Lopez, J. Humberto. 2004. "Pro-growth, pro-poor: is there a tradeoff?," Policy Research Working Paper Series 3378, The World Bank.

Lybbert, T. J., Barrett, C. B., Desta, S., and Coppock, D. L. (2004) Stochastic Wealth Dynamics and Risk Management among a Poor Population. The Economic Journal, 114(498), pp. 750-777.

Naschold, F. (2009) "Poor Stays Poor"- Household Asset Poverty Traps in Rural Semi-Arid India. 2009 Annual Meeting, July 26-28, 2009, Milwaukee, Wisconsin 49396, Agricultural and Applied Economics Association. 
PovcalNet: the on-line tool for poverty measurement developed by the Development Research Group of the World Bank. (http://iresearch.worldbank. org/PovcalNet/index.htm ?1)

Sen, Amartya. 1981. Poverty and Famines: An Essay on Entitlement and Deprivation. Oxford: Clarendon Press

Sen, Amartya. 1999. Development as Freedom. New York. Anchor Books.

Townsend, Peter. 1970. The Concept of Poverty. New york: American Elsevier Publishing Company

UNDP. 2014. Human Development Reports(http://hdr.undp.org/en/ content /table-6-multidimensional-poverty-index-mpi) 